\title{
Enzyme-catalyzed biodegradation of penicillin fermentation residues by $\beta$-lactamase OtLac from Ochrobactrum tritici
}

Peng Wang ${ }^{1,2,3^{*}} \mathbb{D}$, Chen Shen ${ }^{1,2}$, Qinqin Cong ${ }^{1}$, Kaili Xu' and Jialin Lu'

\begin{abstract}
Background: Biodegradation of antibiotics is a promising method for the large-scale removal of antibiotic residues in the environment. However, the enzyme that is involved in the biodegradation process is the key information to be revealed.

Results: In this study, the beta-lactamase from Ochrobactrum tritici that mediates the biodegradation of penicillin $\mathrm{V}$ was identified and characterized. When searching the proteins of Ochrobactrum tritici, the $\beta$-lactamase (OtLac) was identified. OtLac consists of 347 amino acids, and predicted isoelectric point is 7.0. It is a class C $\beta$-lactamase according to BLAST analysis. The coding gene of OtLac was amplified from the genomic DNA of Ochrobactrum tritici. The OtLac was overexpressed in E. coli BL21 (DE3) and purified with $\mathrm{Ni}^{2+}$ column affinity chromatography. The biodegradation ability of penicillin $\vee$ by OtLac was identified in an in vitro study and analyzed by HPLC. The optimal temperature for OtLac is $32^{\circ} \mathrm{C}$ and the optimal pH is 7.0. Steady-state kinetics showed that OtLac was highly active against penicillin $\mathrm{V}$ with a $\mathrm{Km}$ value of $17.86 \mu \mathrm{M}$ and a kcat value of $25.28 \mathrm{~s}^{-1}$ respectively.
\end{abstract}

Conclusions: OtLac demonstrated biodegradation activity towards penicillin $\vee$ potassium, indicating that OtLac is expected to degrade penicillin $\mathrm{V}$ in the future.

Keywords: $\beta$-Lactamase, Biodegradation, Antibiotic, Penicillin V, Ochrobactrum tritici

\section{Introduction}

Antibiotic fermentation residue is the mycelium and culture medium remaining after the end of antibiotic fermentation production [1]. As it contains a large amount of unutilized nutrients such as glucose, corn pulp, peptone, beef extract, and mycelium protein, antibiotic residue is a biological resource with high nutritional value that is easy for organisms to use [1-3]. The traditional feed industry uses antibiotic fermentation waste as a feed additive and manufactures hyphae into animal feed additives to feed the animals. However, because

*Correspondence: pwang@hebust.edu.cn

${ }^{1}$ College of Chemical and Pharmaceutical Engineering, Hebei University of Science and Technology, Shijiazhuang 050018, China

Full list of author information is available at the end of the article these antibiotic bacterial residues contain antibiotics, untreated bacterial residues will cause these antibiotics to accumulate in animals or humans for a long period of time after entering the biological chain, which will lead to drug resistance and cause damage to the environment and ecological flora [4]. Therefore, antibiotic bacterial dregs are regarded as hazardous solid waste, and the use of environmentally friendly methods to process and recycle waste hyphae has become a difficult problem for the companies involved, and it is also an urgent problem for environmental workers.

Penicillin is one of the most widely used antibiotics and it is mainly produced by microbial fermentation [5]. The treatment of penicillin fermentation residues has become a major problem for pharmaceutical companies [6]. Traditional methods for penicillin fermentation residue 
degradation mainly include chemical methods [7], membrane separation [8], activated carbon adsorption [9] and photodegradation [10]. Various traditional bacterial residue treatment methods, including incineration, landfilling and anaerobic digestion $[11,12]$ have also been used. However, because these methods are prone to environmental pollution and inefficient, they have been gradually replaced by various advanced methods. Most recently, with the advancement of technology, many new physical and chemical methods have been developed for the degradation of penicillin antibiotics. For example, the use of photoelectric-Fenton oxidation (PEF) technology for the treatment of ampicillin [13]; the use of ionizing radiation to degrade penicillin [14]; and the use of $\mathrm{UV} / \mathrm{TiO}_{2}$ photocatalytic degradation of amoxicillin can achieve amoxicillin degradation. Penicillin can be degraded by nano $\mathrm{Fe} / \mathrm{Ni}$ (B-Fe/Ni) supported by functional bentonite [15], ZincLoaded materials on a goethite surface [16], $\mathrm{CoFe}_{2} \mathrm{O}_{4} @$ $\mathrm{CuS}$ magnetic nanocomposite and so on [17]. However, these methods are costly, the processing conditions are harsh, and it is difficult to scale up.

Microbiological degradation has become an effective way to address antibiotic contamination due to its advantages, such as high efficiency, low cost and simple operation [18]. This biodegradation method is mainly completed by microbial flora or a certain kind of bacteria in the activated sludge. In recent years, various strains isolated from the environment have been chosen as candidates for the degradation of antibiotic residues [19]. For example, microorganisms isolated from wetland plant root sediments was designed for the treatment of livestock wastewater containing traces of fluoroquinolones and cephalosporins [20]. According to reports, bacteria that can be used for biodegradation of penicillin antibiotics include Pseudomonas [21], Shewanella [22], Bacillus [23], Klebsiella [24] and Paracoccus [25]. However, currently, strain screening and cell-level degradation remain among the studies of the biodegradation of penicillin, and there are few reports from the perspective of the enzymatic and molecular levels, preventing researchers and engineers from developing more efficient and environmentally friendly enzymatic degradation processes.

Enzymes that have been reported to be involved in the biodegradation of penicillin included $\beta$-lactamase and penicillin acylase [26]. However, the research on $\beta$-lactamase has mainly aimed at mediating the occurrence of drug-resistant bacteria $[27,28]$ and the research on penicillin acylase has mainly aimed at the synthesis of synthetic penicillin antibiotics $[29,30]$. As the demand for penicillin antibiotic slag detoxification increases, it is necessary to find more $\beta$-lactamases for the biodegradation of penicillin antibiotics. Since the enzyme catalysis process will not cause the spread of resistance genes or the occurrence of drug-resistant strains, the application of $\beta$-lactamase in the field of harmless antibiotic treatment will make this kind of enzyme friendly for applications in environmental governance and sustainable development.

One of the commonly used slow-onset antibiotics is penicillin $\mathrm{V}$ potassium (PVK) which was used for the treatment of various bacterial infections [31]. Compared to natural penicillin, PVK is more acid resistant to acid, so PVK can be taken orally and is not hydrolyzed by gastric acid. In addition, because PVK has good resistance to hydrolysis, the stability of treating bacterial infections is improved [32]. However, due to the large and widespread use of PVK, high concentrations of PVK have been found in soil, wastewater, and even livestock and poultry manure, which poses a serious threat to the ecological environment and human health, and may cause the appearance of related resistant strains. Therefore, researchers are looking for ways to find the degradation of PVK residues in the environment [23].

In our previous studies, a highly efficient degradation strain for penicillin $\mathrm{V}$ potassium was isolated from the activated sludge by directional breeding [33]. This strain was identified as Ochrobactrum tritici. In the present study, the $\beta$-lactamase candidated in the biodegradation of penicillin $\mathrm{V}$ potassium was identified from the genome of Ochrobactrum tritici. The $\beta$-lactamase was heterologously expressed and purified. The optimal temperature and $\mathrm{pH}$ were studied for enzymatic catalysis. This work provides a novel candidate for penicillin degradation by enzymes.

\section{Materials and methods Materials}

Penicillin V potassium was penicillin G were purchased from Mecklin. IPTG, $\mathrm{NaCl}$ and imidazole were purchased from Mecklin (Shanghai, China). Yeast extract and peptone were purchased from Sigma-Aldrich (St. Louis, MI, USA). All other chemicals, reagents, and solvents such as $\mathrm{Na}_{2} \mathrm{HPO}_{4}, \mathrm{NaH}_{2} \mathrm{PO}_{4}$ and acetonitrile, etc were all purchased from Mecklin (Shanghai, China) and have the highest purity.

\section{Identification of the $\beta$-lactamase from Ochrobactrum tritici} Firstly, the NCBI database was searched to find out $\beta$-lactamase coding genes form Ochrobactrum tritici. Then, dependent on the searched sequences, the primers were designed for amplifying $\beta$-lactamase coding gene in Ochrobactrum tritici X-2 from our lab. And the coding gene was amplified from the genomic of Ochrobactrum tritici X-2 and sequenced to obtained its nucleotide sequence. 


\section{Plasmid construction}

The genomic DNA of Ochrobactrum tritici was extracted using Rapid Bacterial Genomic DNA Isolation Kit (Sangon Biotech China Co., Ltd. Shanghai) The $\beta$-lactamase gene was amplified from genomic DNA of Ochrobactrum tritici using PCR with the primers F (ggaattccatatgAGA AAATCTACGACATTTTTG) and R (cggaattcTTATTG TTTCTTGTCGAGCGCC). Then the PCR product was cloned into pET28a under the restriction sites of $\mathrm{NdeI}$ and EcoRI to obtain pET28a-OtLac to express of OtLac with the 6-His tag at the $\mathrm{N}$-terminus.

\section{Expression and purification of $\beta$-lactamase}

To express the $\beta$-lactamase OtLac, E. coli BL21 (DE3) cells were used. E. coli BL21 (DE3) cells were transformed with the plasmid OtLac and inoculated in LB medium containing $10 \mu \mathrm{g} / \mathrm{mL}$ kanamycin. The E. coli BL21 (DE3) cells were cultured at $37^{\circ} \mathrm{C}$ and $200 \mathrm{rpm}$ until the OD600 reached to $0.4-0.6$ IPTG ( $0.1 \mathrm{mM}$ final concentration) was added to the culture for OtLac expression $E$. coli cells were grown for $12 \mathrm{~h}$ at $20{ }^{\circ} \mathrm{C}$ with shaking at $200 \mathrm{rpm}$. After the induction, the bacteria were collected by centrifugation at $5000 \mathrm{rpm}$, and the E. coli cells were crushed by ultrasonic disruption. The crushed solution was centrifuged at $12000 \mathrm{rpm}$ for $10 \mathrm{~min}$. The supernatant was taken as the crude protein extract for OtLac purification.

OtLac fused with a His tag was purified by using $\mathrm{Ni}^{2+}$-NTA column purification. First, a crude histidinetagged recombinant OtLac protein extract was loaded onto a nickel ion exchange column. Then, two column volumes were eluted with the eluent $\mathrm{A}$ (containing 50 $\mathrm{mM} \mathrm{NaH}_{2} \mathrm{PO}_{4}$ and $300 \mathrm{mM} \mathrm{NaCl}, \mathrm{pH}$ 8), and the eluent B (containing $50 \mathrm{mM} \mathrm{NaH}{ }_{2} \mathrm{PO}_{4}, 300 \mathrm{mM} \mathrm{NaCl}$ and 10 $\mathrm{mM}$ imidazole, $\mathrm{pH} 8$ ). These two column volumes were used for elution of the non-specific binding proteins. The target protein, His-tag fused OtLac, was then eluted with two column volumes (cv) of the eluent $\mathrm{C}$ (containing 50 $\mathrm{mM} \mathrm{NaH}_{2} \mathrm{PO}_{4}, 300 \mathrm{mM} \mathrm{NaCl}$ and $50 \mathrm{mM}$ imidazole, $\mathrm{pH}$ 8). After purification, the eluent $C$ was changed with 50 $\mathrm{mM}$ pH 7.4 sodium phosphate buffer by using a $30 \mathrm{kDa}$ cut-off molecular weight cut-off (MWCO) ultrafiltration tube.

\section{In vitro biocatalysis assay}

Using a reconstituted system using OtLac as the biocatalyst, the substrate conversion in vitro was conducted in vitro. The in vitro catalytic system contained $\beta$ lactamase $(0.5 \mu \mathrm{M})$ in $0.1 \mathrm{M} \mathrm{pH} 7.4$ sodium phosphate buffer. The substrate penicillin V or penicillin $G$ was dissolved in sodium phosphate buffer and added to the in vitro catalytic system so that the final concentration of antibiotic reached $250 \mu \mathrm{M}$. The total reaction volume was $250 \mu \mathrm{L}$, and the reaction temperature was $28{ }^{\circ} \mathrm{C}$. After a $30 \mathrm{~min}$ incubation, the reaction was stopped by adding ethyl acetate $(250 \mu \mathrm{L})$. Extraction was performed twice with ethyl acetate and then the organic extracts were combined, dried and analyzed by HPLC.

\section{Effect of temperature and $\mathrm{pH}$ on biocatalytic activity of $\beta$-lactamase}

In this study, the optimal temperature for the biotransformation of penicillin $\mathrm{V}$ or penicillin $\mathrm{G}$ by purified OtLac was investigated in the temperature range of 20 to $37^{\circ} \mathrm{C}$ at $\mathrm{pH}$ 7.0. Additionally, the influence of $\mathrm{pH}$ on whole cell biotransformation was studied in the $\mathrm{pH}$ range of 6.0-8.5 under the temperature of $28{ }^{\circ} \mathrm{C}$. The incubation time was $30 \mathrm{~min}$.

\section{Steady-state kinetics assays}

The kinetic parameters were estimated with a substrate (penicillin $\mathrm{G}$ or penicillin $\mathrm{A}$ ) concentration range from 0 to $500 \mu \mathrm{M}$ using $0.5 \mu \mathrm{M}$ of OtLac. The in vitro biocatalysis was conducted in $0.1 \mathrm{M}$ sodium phosphate buffer at $\mathrm{pH}$ 7.4. The reactions were started by adding certain concentration of OtLac and quenched after 5 sec by adding two reaction volumes of methanol, and the concentration of the product was determined by HPLC. The Km and kcat values were calculated by plotting the substrate conversion velocities against the substrate concentrations using Michaelis-Menten kinetics and utilizing GraphPad Prism 5 software.

\section{Batch treatment of industrial penicillin fermentation residues by $\beta$-lactamase OtLac from Ochrobactrum tritici}

First, the penicillin bacteria residue was washed three times with water, and ultrasonic treatment was performed during the washing process to fully release the penicillin and other substances in the penicillin bacteria residue. The $\mathrm{pH}$ value of the washing liquid was adjusted to neutral $(\mathrm{pH}=6.8-7.2)$, and $\beta$-lactamase OtLac was added to the washing liquid. The final concentration of the enzyme was $0.25 \mathrm{mg} / \mathrm{mL}$. Samples were taken at different time intervals $(0 \mathrm{~h}, 2 \mathrm{~h}, 6 \mathrm{~h}, 12 \mathrm{~h}, 18 \mathrm{~h}, 24 \mathrm{~h}, 36$ $\mathrm{h}$ and $48 \mathrm{~h}$ ), and the residual amount of penicillin in the washing liquid was determined by HPLC.

\section{HPLC analysis}

The degradation products of penicillin $\mathrm{V}$ potassium were analyzed using an Agilent 1260 HPLC instrument. The degradation products and substrate PVK were separated on a reversed-phase $\mathrm{C} 18$ column at a flow rate of $1 \mathrm{~mL} /$ min. Mobile phase A was $0.5 \mathrm{M}$ potassium dihydrogen phosphate ( $\mathrm{pH}$ was adjusted to 3.5 using phosphate), mobile phase $\mathrm{B}$ was deionized water and mobile phase $\mathrm{C}$ 
was methanol. The ratio of mobile phases $\mathrm{A}, \mathrm{B}$ and $\mathrm{C}$ was set as $1: 4: 5$. The column oven temperature was $30^{\circ} \mathrm{C}$, and the UV absorption was $225 \mathrm{~nm}$.

\section{Results and discussion}

\section{B-Lactamase from Ochrobactrum tritici}

According to the sequence alignment analysis, the sequence of OtLac showed strong homology with class $C$ group $\beta$-lactamase, thus, OtLac was predicted to be a class $C$ group $\beta$-lactamase. The amino acids aligned with the transpeptidase superfamily. Most members of the class $C \beta$-lactamase family are ampicillin hydroxylases. From pairwise alignments, OtLac also had a high amino acid sequence identity with the sequences of accession number P85302, P24735, P94958, O05465 and P45460, showing 55.90\%, 51.70\%, $46.93 \%, 46.91 \%$ and $46.32 \%$ identity, respectively. This high identity suggests that OtLac is a member of the $\beta$-lactamase family and hydrolyses the lactam ring. The sequence alignment between OtLac and various identified $\beta$-lactamase from the Swiss-Prot database is shown in Fig. 1, and the phylogenetic analysis is shown in Fig. 2.

\begin{tabular}{|c|c|c|}
\hline 069773 & $\ldots \ldots \ldots$ MDNS $\ldots \ldots$ MKNIFR.QGRLFIALSLAMTSISAFALTQCEVDDIIKPLMKCECIEGMSVAISVNGKGAIYHYGVQSROTQIPVSDETLYEIGSISKTETA & 94 \\
\hline P05193 & 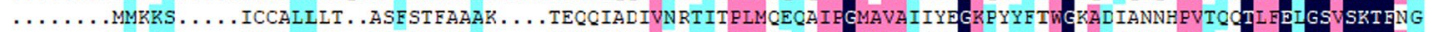 & 91 \\
\hline P05364 & 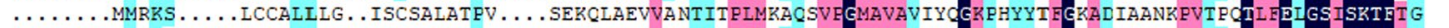 & 91 \\
\hline P00811 & 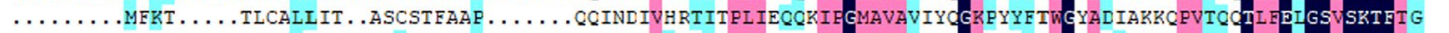 & 87 \\
\hline P18539 & 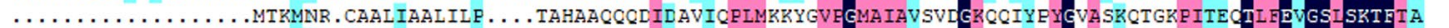 & 86 \\
\hline Q48743 & $\ldots \ldots \ldots \ldots \ldots \ldots$ MKRLIAFCLIFFAALGCARVPPFARSAADAEIORAVAAFMCQYQVAGVAVGITVIGAERYYNY & 91 \\
\hline P45460 & .......MMKKS . . . . IINTLIFTSIATFPLYTLACTK. ITELQVAT IVNNTLTPLIEKQGIEGMAVAVFYIGKPCFFN & 96 \\
\hline 005465 & MRLFTSTLTAKKSSTHKPLISLALSVLISTLLISETACAA. DANDRLECEVDKCAKCLMACYCIEGM: & 109 \\
\hline P94958 & $\ldots \ldots \ldots$ MKKS . . . ISATLISA.LLAFSAPGFS . . . AADNVAAVVDSTIKPLMACQDIHGM & 90 \\
\hline P24735 & $\ldots \ldots \ldots$ MRDTR $\ldots$ FPCLCGIAASTLLFATTPAIAGE. APADRLKALVDAAVQPVMKANDIHGL & 97 \\
\hline P85302 & . . ATDIRQVVD STVEPLMQQQDIZGISVAVIQNGRAQYFNYGVANKDSKQEITENTLFEIGSVSKTHTA & 67 \\
\hline $0 t 13187$ & $\ldots \ldots \ldots$ MRKST $\ldots$ TFLIGFLATAAIIFNSGALAASK. VNDDDLRRIVDETMRPLMAEQKIEGMAVAITIIGRSHF FGYGVASKESGQRVDEITI IEIGSVSKTHTA & 97 \\
\hline Consensus & 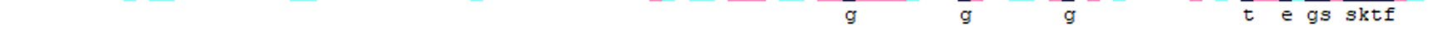 & \\
\hline 069773 & ANIZTHTSE.ISIFVESDIK.TNDCLMAYYCKR̈IEDNEVGCYRSYS & 202 \\
\hline P05193 & 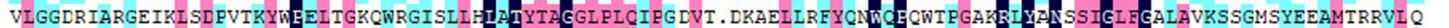 & 200 \\
\hline P05364 & PGGLPLCVPDEVT. DNASILRFYQN WOEOWKPGTTRIY & 200 \\
\hline P00811 & GGLPLCVPDEVK.SSSDILRFYQNWOEAWAFGTCRIY & 196 \\
\hline P18539 & TLAVYAQCQSKLSEKDPASHYIEDVRGSAFDGVSLINIATHTSE. IFIFVED DVT. NNACLMAYYRZWOEKHPAGSYRVY. & 194 \\
\hline Q48743 & GGEF PMCVFT QVK.TDCQITAYEQSWHECYPAGTKRTYZN PGIEMIGVIAAKSMRMPFCKAMTGVLIP & 200 \\
\hline P45460 & 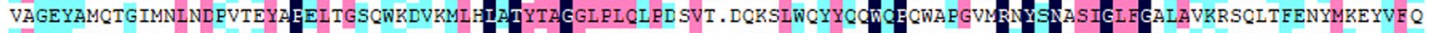 & 205 \\
\hline 005465 & TLASYSELNGTLSIDLTADKYIEYLKNSAIGNTKLISIVTYSAGGYHYRCLKTIE. NNKELLQYYKSWHEDF PVNSKRIYSNASIGLEGYSALSMHSDYTKLIENTVLP & 218 \\
\hline P94958 & 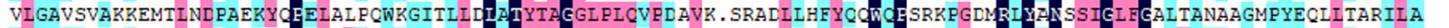 & 199 \\
\hline P24735 & 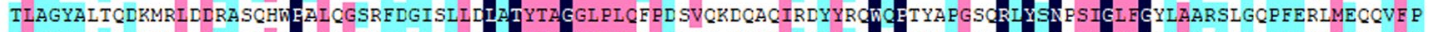 & 207 \\
\hline P85302 & GGLPLCFEEESD.NTGKMISYYQRЙKAFAFGTCEIY & 176 \\
\hline Ot 13187 & TLSGYGLATGAFSLSDPATKWZEELAGSSFDKITMIDI & 206 \\
\hline Consensus & $=-0$ & \\
\hline 069773 & 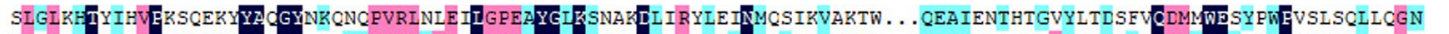 & 309 \\
\hline P05193 & 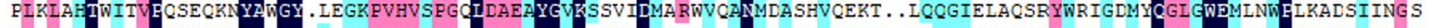 & 307 \\
\hline P05364 & 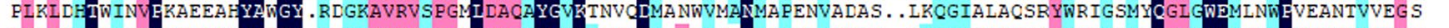 & 307 \\
\hline P00811 & 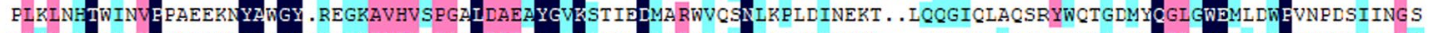 & 303 \\
\hline P18539 & LDAESYGIKSNARDII RYLDZN LQCVKVASVA . . RRWPRRTSV. ITSAGAFTCDIMWENY PYEVKLSRI IEGN & 300 \\
\hline Q48743 & KLGITNTYLTVEFAKMAAYA CGYLDKGCPVRMSPGZIWEFTYGIKTTARDLL RFVEINLDCVKVEPKL . . KRAIDGTHVGYYRLGEMTCGIVWECL PYEASETSLCANS & 307 \\
\hline P45460 & 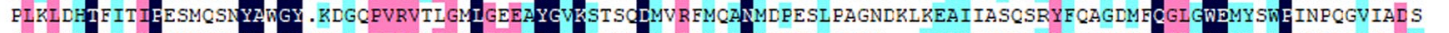 & 314 \\
\hline 005465 & 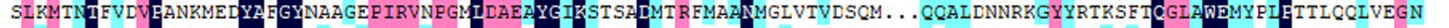 & 325 \\
\hline P9495.8 & PLGISHTFITVEESAQSQYAYGY . KNKKPVRVSPGCIDAESYGVESASKDML RWAEMNMEFSRAGNAD . LEMAMYLACTRYYKTAAINCGIGWEMYDKECOKDMI INGV & 306 \\
\hline P24735 & 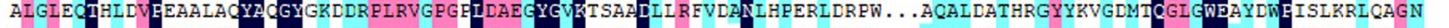 & 314 \\
\hline P85302 & 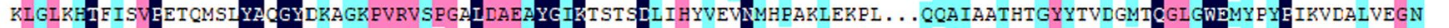 & 283 \\
\hline Ot 13187 & AFGLKNTFVNVEESRMKNYZYGYSKADKFIRVSGGZLDACAYGIKTTALDLARFIELNIDSSSLEPDF . . CKAVAATHTGYYHVGANNQGIGWEFYSYETALKTLLAGN & 313 \\
\hline Consensus & 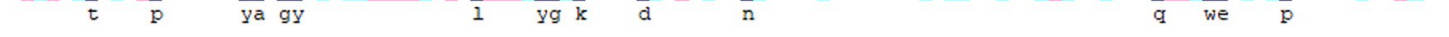 & \\
\hline 069773 & 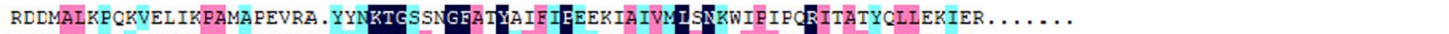 & 384 \\
\hline P05193 & DSKVAIAALPAVEVNPEAFAVKAS.WVHKTGSTGGGGSYVAFVEEKNLGIVMIZNRSYPNPAEVEAAWRIIEKLC $\ldots \ldots$ & 381 \\
\hline P05364 & DSKVALAPLPVAEVNPEAP PVKAS.WVHKTESTGGEGSYVAFIEEKCIGIVMIZNTSYPNPAFVEAAYHILEALQ $\ldots \ldots$ & 381 \\
\hline P00811 & DNKIAIAARPVKA ITPETPAVRAS. WVHKTGATGGGGSYVAFIEEKELG IVM LZNKNYPNPARVDAAWCIINALQ $\ldots \ldots \ldots$ & 377 \\
\hline P18539 & NAGM IMNGTPATA ITPFQ. PELRAGWYNKTESTGGFSTYAVF IEAKNIAVENIZNKWF PNDLRVEAAYHIICALEKR $\ldots \ldots$ & 376 \\
\hline Q48743 & 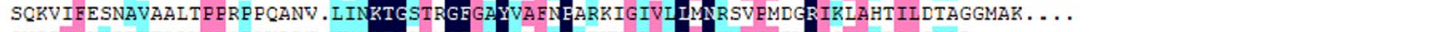 & 385 \\
\hline P45460 & GNDIAIKPRKVEALVPAQPAVRAS.WVHKTGATNGFGZYIVFIEEEKVGIVIIZNKNYPNFVRVCAAYDIICALR $\ldots \ldots$ & 388 \\
\hline 005465 & STET IIQPGPIQLNEPETPVLNDV. WVNKTGATNGEGZYIAYMEAKKTGMFILZNKNYENTERVKAAYTIIDSVMNN . . . . & 401 \\
\hline P94958 & 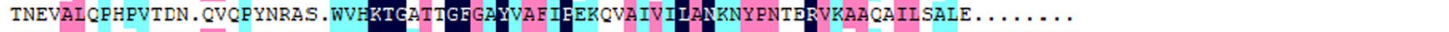 & 379 \\
\hline P24735 & STPMAICPHRIARLFAFCALEGCR. LLNKTGSTNGFGPYVAFVEGRDLGLVILZNRNYFNABEVKIAYAIISGLECCGKVELK & 396 \\
\hline P85302 & STQMAMEPHKVNWLTPEQAAPLDT. LVNKTGSTGGGGZYVAYVESKGLGVVILZNKNYFNAEEVKAAHAIISAMDQ $\ldots \ldots$ & 358 \\
\hline $0 t 13187$ & 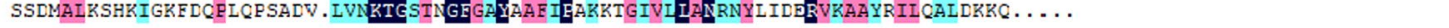 & 390 \\
\hline Consensus & $\begin{array}{llllll}\mathrm{ktg} & \mathrm{gf} & \mathrm{y} & \mathrm{p} & \mathrm{l} \mathrm{n} & \mathrm{r}\end{array}$ & \\
\hline \multicolumn{3}{|c|}{$\begin{array}{l}\text { Fig. } 1 \text { Sequence alignment of OtLac and various } \beta \text {-lactamase. Amino acid sequence alignment was performed using ClustalW. (The selected } \\
\text { sequences: P05193: Citrobacter freundii; P00811: Escherichia coli (strain K12); P05364: Enterobacter cloacae; P45460: Yersinia enterocolitica; P94958: } \\
\text { Morganella morganii; P24735: Pseudomonas aeruginosa; P85302: Pseudomonas fluorescens; O05465: Psychrobacter immobilis; Q48743: Lysobacter } \\
\text { lactamgenus; O69773: Providencia stuartii; P18539: Serratia marcescens) }\end{array}$} \\
\hline
\end{tabular}




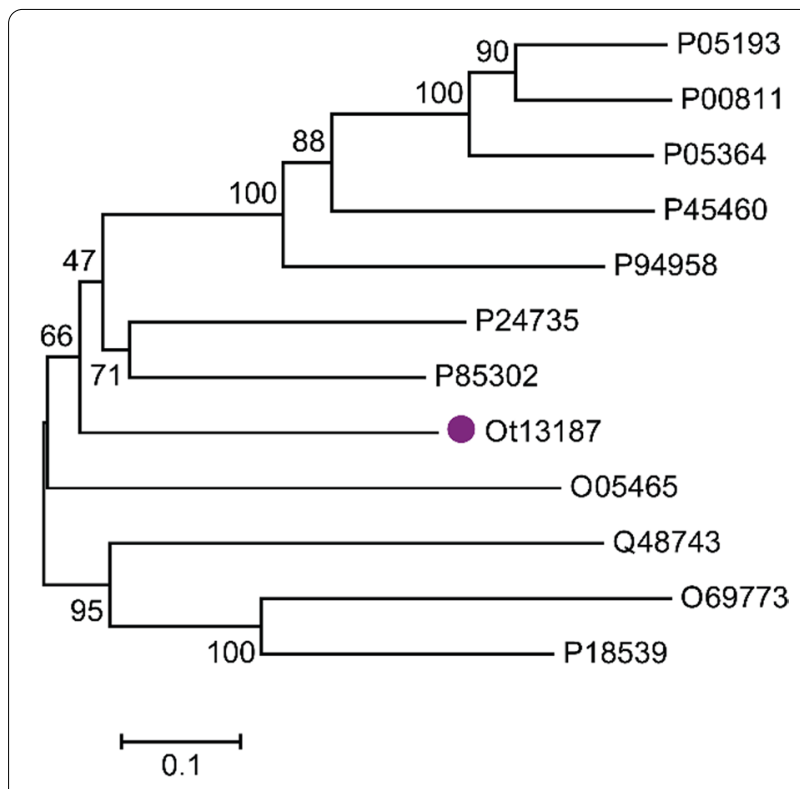

Fig. 2 Phylogenetic tree of OtLac (Ot13187) from Ochrobactrum tritici and other functionalized $\beta$-lactamases from the Swiss-Prot database. Amino acid sequence alignment was performed using ClustalW. The tree was constructed using a neighbor-joining algorithm and 1000 repeated guided analyses. Guide values are displayed on the branch nodes. The scale bar represents 0.2 amino acid substitutions per amino acid. The OtLac (Ot13187) from Ochrobactrum tritici is indicated with the closed circle (

\section{Cloning and recombinant expression of $\beta$-lactamase}

The coding gene of OtLac was amplified from the genomic DNA of Ochrobactrum tritici using PCR. The PCR product was approximately $1.2 \mathrm{~kb}$. Then, the PCR product of OtLac was cloned into the pET28a vector. $E$. coli BL21 (DE3) cells were used for the efficient expression of OtLac. IPTG was added for inducing the OtLac

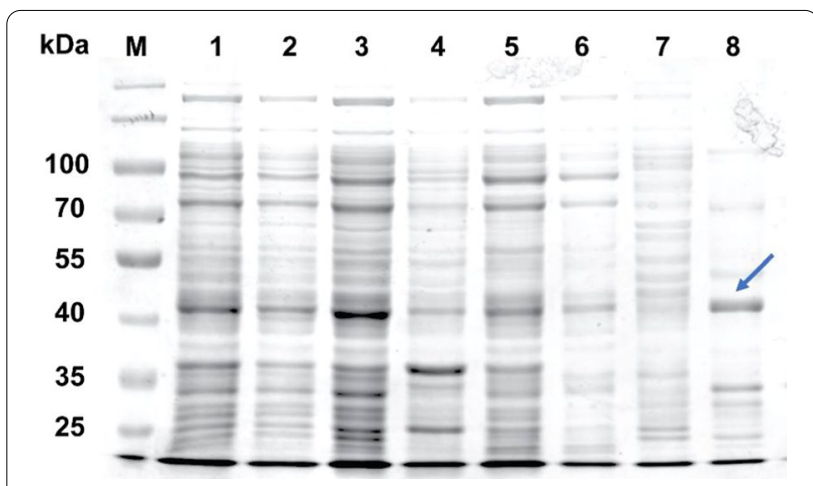

Fig. 3 Expression and purification of OtLac (SDS-PAGE of expression and purification of OtLac, protein samples were taken at different stages of expression and purification. Lane M, prestained protein marker. Lane 1, cell lysate before induction with IPTG. Lane 2, cell lysate after $24 \mathrm{~h}$ of expression. Lane 3 , cell free supernatant after sonication. Lane 4, precipitation of cells. Lane 5, Proteins that do not bind to $\mathrm{Ni}^{2+}$ gel. Lane 6, 2 mM imidazole eluent. Lane $710 \mathrm{mM}$ imidazole eluent. Lane 8, purified OtLac) with $50 \mathrm{mM}$ imidazole eluent

expression. The expression of OtLac was analysed by SDS-PAGE which is shown in Fig. 3C.

\section{Purification of $\beta$-lactamase}

In this study, nickel affinity chromatography was used to purify the histidine-tagged fused OtLac. The OtLac gene was cloned into the NdeI and EcoRI cloning sites in the vector pET28a $(+)$ to generate a recombinant protein with an N-terminal His6 tag. E. coli BL21 (DE3) was cultured at $20{ }^{\circ} \mathrm{C}$ for protein expression, yielding a recombinant protein of up to $14 \%$ of the total soluble protein with a molecular weight of $43 \mathrm{kDa}$. A metal chromatography column was used to elute the protein sample, and
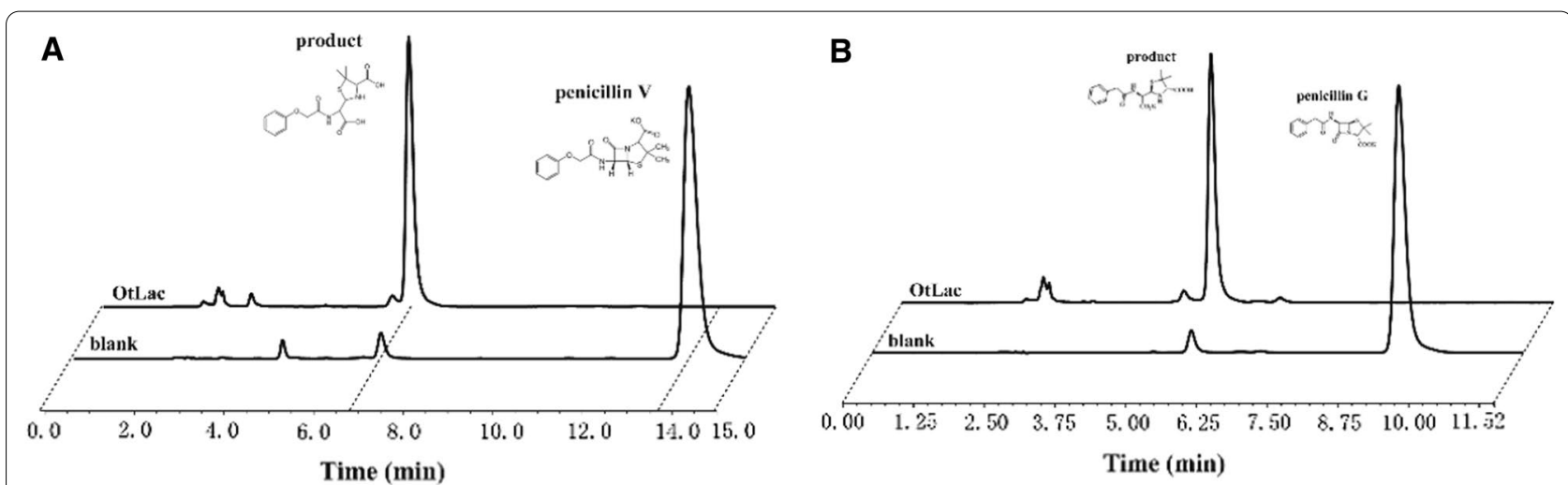

Fig. 4 In vitro biodegradation of penicillin $\vee$ and penicillin G by OtLac. A HPLC analysis of penicillin V degradation by OtLac, the retention time of penicillin $V$ and its product was 13.71 min and 6.77 min respectively. B HPLC analysis of penicillin G degradation by OtLac, the retention time of penicillin $\mathrm{G}$ and its product was 9.23 min and 5.89 min respectively 

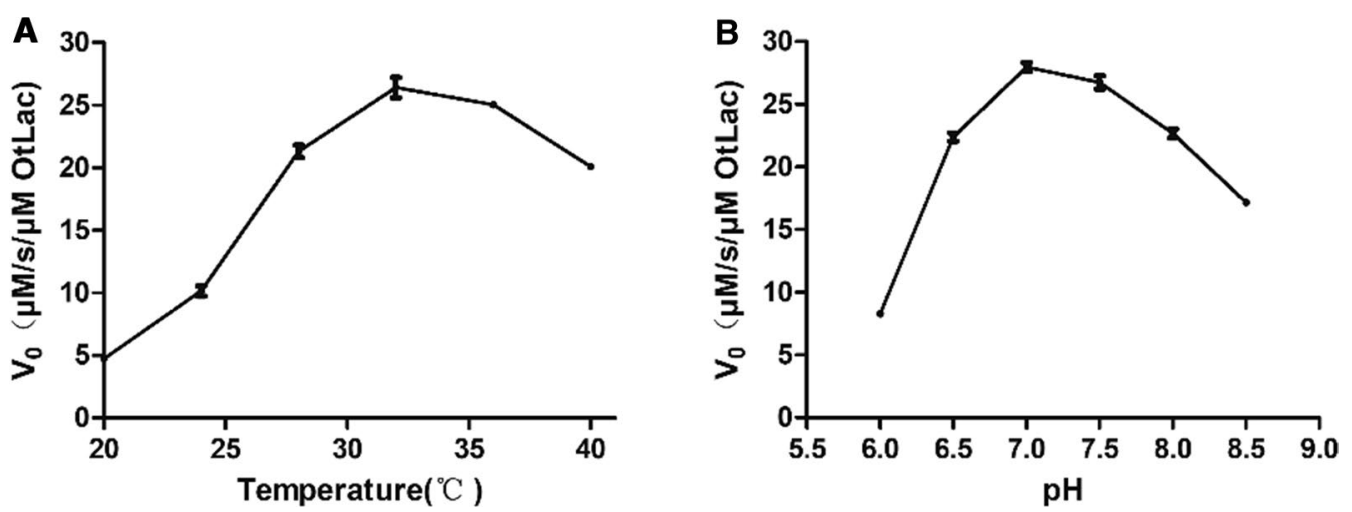

Fig. 5 Effects of temperature and pH on the biocatalytic activity of OtLac. The incubation time was $30 \mathrm{~min}$. And the $\mathrm{pH}$ test was conducted under the temperature of $28^{\circ} \mathrm{C}$

a $50 \mathrm{mM}$ imidazole eluate was collected to obtain a pure enzyme, as shown in Fig. 3C. The protein was concentrated using an ultrafiltration membrane. By Bradford analysis, $140 \mathrm{mg}$ of pure OtLac can be obtained from 500 $\mathrm{mL}$ of culture and the purity of the enzyme was determined to be $92.81 \%$.

\section{In vitro biotransformation of penicillin $\mathrm{V}$ and penicillin $\mathrm{G}$ by OtLac}

In order to identify the biocatalytic ability and efficiency of penicillin $\mathrm{V}$ and penicillin $\mathrm{G}$ by OtLac, an in vitro biocatalytic study was conducted. A reaction mixture containing the $\beta$-lactamase was used for the in vitro bioconversion of penicillin $\mathrm{V}$ and penicillin $\mathrm{G}$, while a reaction mixture without $\beta$-lactamase was used as a negative control. The biocatalytic properties of penicillin $\mathrm{V}$ or penicillin $\mathrm{G}$ were determined by HPLC analysis. A diode array detector (DAD) was used for substance detection. As shown in Fig. 4, only when the reaction system contained OtLac can the biotransformation products can be detected during the catalytic reaction, which indicates

Table 1 comparison of OtLac with other class C $\beta$-lactamases

\begin{tabular}{lllll}
\hline Enzyme & Substrate & $\mathbf{K m}(\boldsymbol{\mu M})$ & kcat & Reference \\
\hline OtLac & Penicillin V & 17.86 & 25.28 & This study \\
ADC-1 & Ampicillin & 32 & 4.8 & {$[34]$} \\
& Benzylpenicillin & 5.1 & 10.26 & \\
& Oxacillin & 12.32 & 0.046 & \\
& Piperacillin & 6.4 & 3.1 & \\
ACT-3 AmpC & Penicillin G & 26 & & {$[35]$} \\
CMY-10 & Benzylpenicillin & 20.5 & 3.06 & {$[36]$} \\
YOC-1 & Benzylpenicillin & 934.2 & 178,900 & {$[37]$} \\
& Ampicillin & 109.4 & 5533.33 & \\
LHK-5 & Benzylpenicillin & 356 & & {$[38]$} \\
\hline
\end{tabular}

that OtLac has bioconversion penicillin $\mathrm{G}$ and penicillin $\mathrm{V}$ bioconversion activity. The penicillin $\mathrm{V}$ product had a retention time of $6.77 \mathrm{~min}$, and we proposed that this was the corresponding lactam ring cleavage product. The penicillin $\mathrm{G}$ product retention time is $5.89 \mathrm{~min}$, and we proposed that this was the corresponding lactam ring cleavage product.

\section{Influence of temperature and $\mathrm{pH}$ on biocatalytic activity of the $\beta$-lactamase from Ochrobactrum tritici}

The optimal temperature for OtLac activity was investigated over the temperature range of $20-40{ }^{\circ} \mathrm{C}$ (Fig. 5A). The results indicated that the optimal temperature of OtLac was $32{ }^{\circ} \mathrm{C}$. Thermostability data showed that OtLac was thermolabile with an approximate half-life of $30 \mathrm{~min}$ at $40{ }^{\circ} \mathrm{C}$. In order to study the optimal $\mathrm{pH}$ for OtLac, various $\mathrm{pH}$ values ranging from 6.0 to 9.0 were tested. The preferred $\mathrm{pH}$ of OtLac was over the range from 7.0 to 7.5.

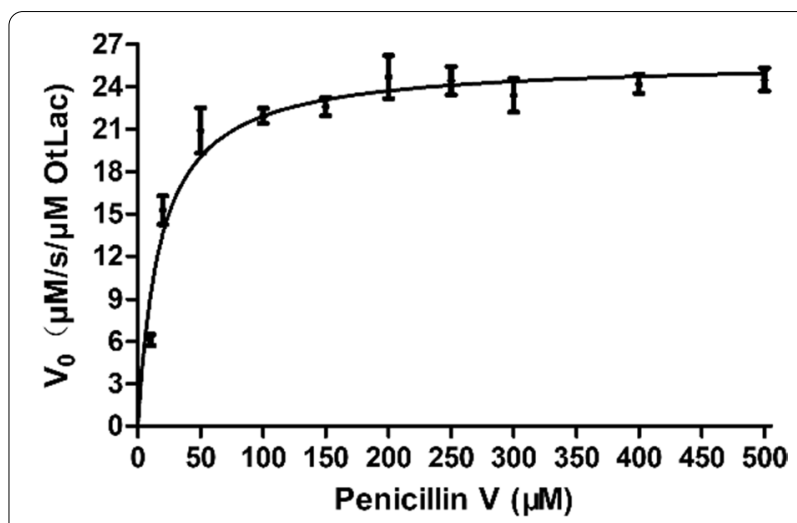

Fig. 6 Determination of the $\mathrm{Km}$ value for penicillin $\mathrm{V}$ bio-catalyzed by OtLac. The relationship between the maximum reaction rate and the substrate concentration is plotted. GraphPad Prism 5 software was used to fit the average of three independent measurements 

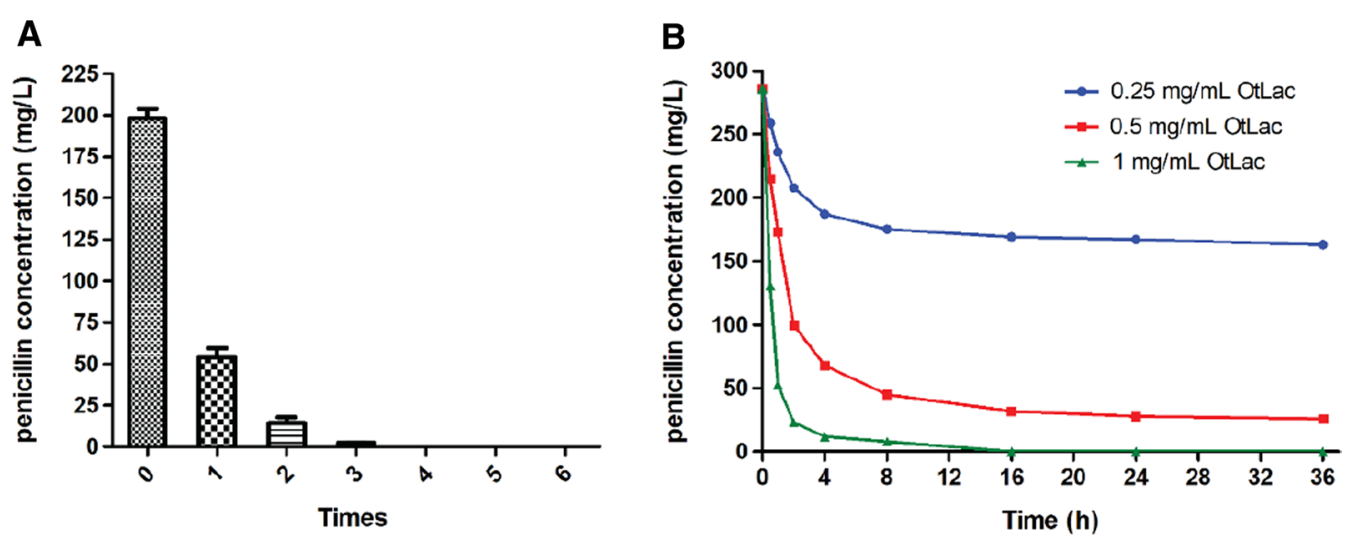

Fig. 7 Biodegradation of industrial penicillin $\mathrm{G}$ fermentation residues by OtLac. A The relationship between penicillin concentration and extract times with ultrasonic. B Time course of industrial penicillin fermentation residue biodegradation by varies concentration of OtLac $(0.25 \mathrm{mg} / \mathrm{mL}, 0.5$ $\mathrm{mg} / \mathrm{mL}, 1 \mathrm{mg} / \mathrm{mL})$

Kinetic assays of OtLac towards penicillin $\mathrm{V}$ and penicillin $\mathrm{G}$ The kinetic constant of the enzymatic reaction of purified OtLac to penicillin $\mathrm{V}$ was studied. The tested concentrations of substrate PVK ranged from 10 to $300 \mu \mathrm{M}$, and the kcat, and $\mathrm{Km}$ values were $25.82 \mathrm{~s}^{-1}$, and $17.86 \mu \mathrm{M}$, respectively. The kinetic constant of the enzymatic reaction of purified OtLac to penicillin $G$ was also studied. The substrate concentration was $10-500 \mu \mathrm{M}$, giving kcat, and $\mathrm{Km}$ values of $22.28 \mathrm{~s}^{-1}$, and $32.75 \mathrm{mM}$, respectively. These results suggested that OtLac was more efficient for penicillin $\mathrm{V}$ biodegradation.

$\beta$-Lactamases of class $C$ are widely distributed on the chromosomes of many Gram-negative species. They can catalyze wide range of substrates like penicillin, Cephalothin, Meropenem, et al. In this study, it was the first report for this class of $\beta$ lactamase for catalyze penicillin V. The comparison of OtLac with other class $C$ $\beta$-lactamase for different substrates was shown in Table 1.

\section{Treatment of an industrial penicillin fermentation residue by OtLac}

OtLac was used to treat the industrial penicillin fermentation residues. First, we investigated the optimal number of times for penicillin extraction from the residue by ultrasonic extraction. Ultrasonic extraction was repeated six times, and after three extractions, penicillin could no longer be detected in the extract water, as shown in Fig. 6A. Thus, the optimal number of extraction times was three. Next, the industrial penicillin fermentation-extracted water was treated with OtLac. Various concentrations $\left(0.25 \mathrm{mg} \mathrm{mL}^{-1}, 0.5 \mathrm{mg} \mathrm{mL}{ }^{-1}\right.$ and $1 \mathrm{mg} \mathrm{mL}^{-1}$ ) of OtLac were used for penicillin biodegradation. As shown in Fig. 6B, in the first $1 \mathrm{~h}$, the biodegradation rate was the same among the tested enzyme concentrations, which were $200 \mathrm{mg} \mathrm{h} / \mathrm{mg}^{-1}$, $226 \mathrm{mg} \mathrm{h}^{-1} \mathrm{mg}^{-1}$ and $233 \mathrm{mg} \mathrm{h}^{-1} \mathrm{mg}^{-1}$, respectively. However, an hour later, the biodegradation rate was slightly decreased and after two h, the biodegradation was significantly decreased. These phenomena indicated that the enzymatic activity could be maintained in the first hour but was severely inactivated after $2 \mathrm{~h}$. When the concentration of OtLac was $1 \mathrm{mg} \mathrm{mL}^{-1}$, penicillin was easily degraded. Our study was conducted with free enzymes, which are easily influenced by factors in the external environment, such as $\mathrm{pH}$, metal irons and other toxins. This problem can be solved by immobilization, degradation-separation coupling processed and even enzyme evolution methods (Fig. 7).

\section{Conclusion}

In this study, the $\beta$-lactamase OtLac was identified and characterized from Ochrobactrum tritici was shown to possess biodegradation ability for both penicillin $G$ and penicillin V. OtLac is a class $C \beta$-lactamase as analysed by sequence alignment. The biocatalytic efficiency for PG and PV of OtLac was much higher than that reported for other class $\mathrm{C} \beta$-lactamases, making it a potential candidate for the enzymatic biodegradation of $\beta$-lactam antibiotic degradation in the environment.

\section{Acknowledgments \\ Not applicable.}

\section{Authors' contributions}

PW and CS conceived the study, carried out the experiments, and drafted the manuscript. QC and CS participated in the biodegradation study. KX, QC, and $\mathrm{CS}$ assisted in the genetic engineering experiments. All authors read and approved the final manuscript. 


\section{Funding}

This work was financially supported by National Natural Science Foundation of China (21978068, 21978067), Hebei Province Science and Technology Support Plan (16273812), The Excellent Going Abroad Experts'Training Program in Hebei Province and Hebei Province High-level Talents Funded Project.

\section{Availability of data and materials}

Not applicable.

\section{Declaration}

Ethics approval and consent to participate

Not applicable.

\section{Consent for publication}

Not applicable.

\section{Competing interests}

The authors declare that they have no competing interests.

\section{Author details}

${ }^{1}$ College of Chemical and Pharmaceutical Engineering, Hebei University of Science and Technology, Shijiazhuang 050018, China. ${ }^{2}$ State Key Laboratory Breeding Base-Hebei Province Key Laboratory of Molecular Chemistry for Drug, Hebei University of Science and Technology, Shijiazhuang 050018, China. ${ }^{3}$ Hebei Province Pharmaceutical Chemical Engineering Technology Research Center, Shijiazhuang 050018, China.

Received: 23 January 2021 Accepted: 5 June 2021 Published online: 13 June 2021

\section{References}

1. Yang G, Wang J, Shen Y. Antibiotic fermentation residue for biohydrogen production using different pretreated cultures: performance evaluation and microbial community analysis. Bioresour Technol. 2019;292:122012.

2. Hu J, Hong C, Li Z, Xing Y, Zheng Z, Zhao X, Wang Z, Zhao H, Zhang Z, Meng J, Qi C. Nitrogen release of hydrothermal treatment of antibiotic fermentation residue and preparation of struvite from hydrolysate. Sci Total Environ. 2020;713:135174.

3. Wang Z, Hong C, Xing Y, Li Z, Li Y, Yang J, Feng L, Hu J, Sun H. Thermal characteristics and product formation mechanism during pyrolysis of penicillin fermentation residue. Bioresour Technol. 2019;277:46-54.

4. Wang B, Yan J, Li G, Zhang J, Zhang L, Li Z, Chen H. Risk of penicillin fermentation dreg: increase of antibiotic resistance genes after soil discharge. Environ Pollut. 2020;259:113956.

5. Wang G, Chu J, Noorman H, Xia J, Tang W, Zhuang Y, Zhang S. Prelude to rational scale-up of penicillin production: a scale-down study. Appl Microbiol Biotechnol. 2014;98:2359-69.

6. Wang B, Li G, Cai C, Zhang J, Liu H. Assessing the safety of thermally processed penicillin mycelial dreg following the soil application: organic matter's maturation and antibiotic resistance genes. Sci Total Environ. 2018;636:1463-9.

7. Mitchell SM, Ullman JL, Teel AL, Watts RJ. Hydrolysis of amphenicol and macrolide antibiotics: Chloramphenicol, florfenicol, spiramycin, and tylosin. Chemosphere. 2015;134:504-11.

8. Sui Q, Jiang C, Zhang J, Yu D, Chen M, Wang Y, Wei Y. Does the biological treatment or membrane separation reduce the antibiotic resistance genes from swine wastewater through a sequencing-batch membrane bioreactor treatment process. Environ Int. 2018;118:274-81.

9. Wang S, Li X, Zhao H, Quan X, Chen S, Yu H. Enhanced adsorption of ionizable antibiotics on activated carbon fiber under electrochemical assistance in continuous-flow modes. Water Res. 2018;134:162-9.

10. Wang $Y$, Qiao $M, L v J$, Xu G, Zheng Z, Zhang X, Wu Y. g- $C_{3} N_{4} / g-C_{3} N_{4}$ isotype heterojunction as an efficient platform for direct photodegradation of antibiotic. Fuller Nanotub Carb Nanostruct. 2018;26:210-7.

11. Yu Z, He P, Shao L, Zhang H, Lu F. Co-occurrence of mobile genetic elements and antibiotic resistance genes in municipal solid waste landfill leachates: a preliminary insight into the role of landfill age. Water Res. 2016;106:583-92
12. Wallace JS, Garner E, Pruden A, Aga DS. Occurrence and transformation of veterinary antibiotics and antibiotic resistance genes in dairy manure treated by advanced anaerobic digestion and conventional treatment methods. Environ Pollut. 2018;236:764-72.

13. Villegas-Guzman P, Silva-Agredo J, Florez O, Giraldo-Aguirre AL, Pulgarin C, Torres-Palma RA. Selecting the best AOP for isoxazolyl penicillins degradation as a function of water characteristics: effects of $\mathrm{pH}$, chemical nature of additives and pollutant concentration. J Environ Manag. 2017:190:72-9.

14. Ben Salem I, Mezni M, Boulila A, Hamdi M, Saidi M. Removal of penicillin $\mathrm{G}$ and erythromycin with ionizing radiation followed by biological treatment. Curr Microbiol. 2016;73:582-6.

15. Tran ML, Fu CC, Juang RS. Removal of metronidazole and amoxicillin mixtures by $\mathrm{UV} / \mathrm{TiO}_{2}$ photocatalysis: an insight into degradation pathways and performance improvement. Environ Sci Pollut Res Int. 2019;26:11846-55.

16. Sheng F, Ling J, Wang C, Jin X, Gu X, Li H, Zhao J, Wang Y, Gu C. Rapid hydrolysis of penicillin antibiotics mediated by adsorbed zinc on goethite surfaces. Environ Sci Technol. 2019;53:10705-13.

17. Kamranifar M, Allahresani A, Naghizadeh A. Synthesis and characterizations of a novel $\mathrm{CoFe}_{2} \mathrm{O}_{4} @ \mathrm{CuS}$ magnetic nanocomposite and investigation of its efficiency for photocatalytic degradation of penicillin $\mathrm{G}$ antibiotic in simulated wastewater. J Hazard Mater. 2019;366:545-55.

18. Li B, Zhang T. Biodegradation and adsorption of antibiotics in the activated sludge process. Environ Sci Technol. 2010;44:3468-73.

19. Bilal M, Ashraf SS, Barceló D, lqbal HMN. Biocatalytic degradation/redefining "removal" fate of pharmaceutically active compounds and antibiotics in the aquatic environment. Sci Total Environ. 2019;691:1190-211.

20. Alexandrino DAM, Mucha AP, Almeida CMR, Gao W, Jia Z, Carvalho MF. Biodegradation of the veterinary antibiotics enrofloxacin and ceftiofur and associated microbial community dynamics. Sci Total Environ. 2017;581-582:359-68.

21. Lin B, Lyu J, Lyu XJ, Yu HQ, Hu Z, Lam JC, Lam PK. Characterization of cefalexin degradation capabilities of two pseudomonas strains isolated from activated sludge. J Hazard Mater. 2015;282:158-64.

22. Liu H, Yang Y, Ge Y, Zhao L, Long S, Zhang R. Interaction between common antibiotics and a Shewanella strain isolated from an enhanced biological phosphorus removal activated sludge system. Bioresour Technol. 2016;222:114-22.

23. Yang X, Li M, Guo P, Li H, Hu Z, Liu X, Zhang Q. Isolation, screening, and characterization of antibiotic-degrading bacteria for penicillin $v$ potassium (PVK) from soil on a pig farm. Int J Environ Res Public Health. 2019;16:2166

24. Wang P, Liu H, Fu H, Cheng X, Wang B, Cheng Q, Zhang J, Zou P. Characterization and mechanism analysis of penicillin $G$ biodegradation with Klebsiella pneumoniae $\mathrm{Z1}$ isolated from waste penicillin bacterial residue. $J$ Ind Eng Chem. 2015;27:50-8.

25. Wang P, Shen C, Wang X, Liu S, Li L, Guo J. Biodegradation of penicillin $G$ from industrial bacteria residue by immobilized cells of Paracoccus sp KDSPL-02 through continuous expanded bed adsorption bioreactor. J Biol Eng. 2020;14:5.

26. Crofts TS, Wang B, Spivak A, Gianoulis TA, Forsberg KJ, Gibson MK, Johnsky LA, Broomall SM, Rosenzweig CN, Skowronski EW, et al. Shared strategies for beta-lactam catabolism in the soil microbiome. Nat Chem Biol. 2018;14:556-64.

27. Bush K, Bradford PA. Interplay between beta-lactamases and new betalactamase inhibitors. Nat Rev Microbiol. 2019;17:295-306.

28. Bush K, Bradford PA. Epidemiology of $\beta$-lactamase-producing pathogens. Clin Microbiol Rev. 2020. https://doi.org/10.1128/CMR.00047-19.

29. Srirangan K, Orr V, Akawi L, Westbrook A, Moo-Young M, Chou CP. Biotechnological advances on penicillin $\mathrm{G}$ acylase: pharmaceutical implications, unique expression mechanism and production strategies. Biotechnol Adv. 2013;31:1319-32.

30. Borčinová M, Raschmanová H, Zamora I, Looser V, Marešová H, Hirsch S, Kyslík P, Kovar K. Production and secretion dynamics of prokaryotic Penicillin G acylase in Pichia pastoris. Appl Microbiol Biotechnol. 2020;104:5787-800

31. Ben Salem A, Sautrey G, Fontanay S, Duval RE, Regnouf-de-Vains JB. Molecular drug-organiser: synthesis, characterization and biological evaluation of penicillin $\mathrm{V}$ and/or nalidixic acid calixarene-based podands. Bioorg Med Chem. 2011;19:7534-40. 
32. Leung HW, Minh TB, Murphy MB, Lam JC, So MK, Martin M, Lam PK, Richardson BJ. Distribution, fate and risk assessment of antibiotics in sewage treatment plants in Hong Kong. South China Environ Int. 2012;42:1-9.

33. Wang P, Shen C, Xu K, Cong Q, Dong Z, Li L, Guo J, Lu J, Liu S. Isolation and characterization of Ochrobactrum tritici for penicillin v potassium degradation. mSphere. 2020. https://doi.org/10.1128/mSphere.00058-20.

34. Bhattacharya $M$, Toth $M$, Antunes NT, Smith CA, Vakulenko SB. Structure of the extended-spectrum class C $\beta$-lactamase ADC-1 from Acinetobacter baumannii. Acta Crystallogr Sect D Biol Crystallogr. 2014. https://doi.org/ 10.1128/mSphere.00058-20.

35. Cheong Hae Suk, Peck KR, Ko KS. ACT-3, a novel plasmid-encoded class C $\beta$-lactamase in a Klebsiella pneumoniae isolate from China. Intern J Antimicrob Agents. 2009;33:8.

36. Kim JY, Jung HI, An YJ, Lee JH, Kim SJ, Jeong SH, Lee KJ, Suh P-G, Lee H-S, Lee $\mathrm{SH}$, Cha S-S. Structural basis for the extended substrate spectrum of CMY-10, a plasmid-encoded class C $\beta$-lactamase. Mol Microbiol. 2006;60:10.
37. Zhou D, Sun Z, Junwan Lu, Liu H, Wei Lu, Lin H, Zhang X, Li Q, Zhou W, Zhu $X$, et al. Characterization of a novel chromosomal class $c \beta$-lactamase, yoc-1, and comparative genomics analysis of a multidrug resistance plasmid in Yokenella regensburgei W13. Front Microbiol. 2020;11:11.

38. Lau SKP, Ho P-I, Li MWS, Tsoi H-W, Yung RWH, Woo PCY, Yuen K-Y. Cloning and characterization of a chromosomal class $C \beta$-lactamase and its regulatory gene in Laribacter hongkongensis. Antimicrob Agents Chemother. 2005;49:8.

\section{Publisher's Note}

Springer Nature remains neutral with regard to jurisdictional claims in published maps and institutional affiliations.
Ready to submit your research? Choose BMC and benefit from:

- fast, convenient online submission

- thorough peer review by experienced researchers in your field

- rapid publication on acceptance

- support for research data, including large and complex data types

- gold Open Access which fosters wider collaboration and increased citations

- maximum visibility for your research: over $100 \mathrm{M}$ website views per year

At BMC, research is always in progress.

Learn more biomedcentral.com/submissions 